\title{
Farklı Kökenli Bazı Pamuk Genotiplerinde Verticillium Solgunluğuna Dayanıklılı̆̆ın Araştırılması
}

\author{
Yaşar AKIŞCAN1, Fatih Mehmet TOK ${ }^{2}$ \\ ${ }^{1}$ Hatay Mustafa Kemal Üniversitesi, Ziraat Fakültesi, Tarla Bitkileri Bölümü, Antakya, Hatay, ${ }^{2}$ Hatay Mustafa Kemal Üniversitesi, Ziraat \\ Fakültesi, Bitki Koruma Bölümü, Antakya, Hatay \\ ${ }^{1}$ https://orcid.org/0000-0002-3302-7766, ${ }^{2}$ https://orcid.org/0000-0003-4199-6097 \\ $\bowtie:$ ftok@mku.edu.tr
}

\section{ÖZET}

$\mathrm{Bu}$ çalışma, farklı kökenli bazı pamuk genotiplerinin Verticillium solgunluğu hastalığına dayanıklılık durumlarını tespit etmek amacıyla yapılmıştır. Çalışma, tesadüf blokları deneme deseni uyarınca, üç tekerrürlü olarak kontrollü iklim kabininde yürütülmüştür. Çalışmada inokulasyon işlemi, bitkilerinin 2-3 gerçek yaprağa sahip olduğu dönemde, kökleri $V$. dahliae'nın $\mathrm{T}_{1}$ patotipine ilişkin izolatının $10^{7}$ konidi $\mathrm{ml}^{-1}$ konsantrasyonundaki spor süspansiyonuna daldırılarak yapılmıştır. Çalışma sonucunda, genotiplerin yaprak ve iletim dokusu semptomlarına göre, hastalık indeksi değerleri arısındaki farklılıkların, istatistiksel olarak \% 1 düzeyinde önemli olduğu saptanmıştır. Çalışmada incelenen genotiplere ilişkin hastalık indeksi değerlerinin yaprak semptomlarina göre istatistiksel olarak 13; iletim dokusu semptomlarına göre ise 16 farklı grupta toplandığ tespit edilmiştir. Materyal olarak kullanılan pamuk genotipleri arasında, yaprak semptomlarına göre, hastalığa en dayanıklı genotiplerin sırasıyla ABD kökenli Tamcot Camd-ES (1.39), Türkiye kökenli PG 510-7 (1.64) ve BA-525 (1.72); iletim dokusu semptomlarına göre ise sırasıyla ABD kökenli Tamcot Camd-ES (1.31), Türkiye kökenli PG 510-7 (1.47) ve İH-26-K-5 olduğu saptanmıştır. Bu çalışma sonucunda, genotiplere ilişkin olarak yaprak ve iletim dokularındaki semptomlara göre elde edilen hastalık indeksi değerleri arasında yüksek düzeyde pozitif yönde korelasyon $(r=0.972)$ olduğu saptanmıştır.

Araştırma Makalesi

Makale Tarihçesi
Geliş Tarihi : 25.03 .2019

Kabul Tarihi : 22.08 .2019

Anahtar Kelimeler

Gossypium hirsutum

Verticillium dahliae

Yaprak semptomları

İletim dokusu semptomları

\section{Investigation of Resistance to Verticillium Wilt in Some Cotton Genotypes with Different Origins}

\section{ABSTRACT}

The aim of this study was to determine the resistance of some genotypes with different origins against Verticillium wilt. The study was conducted in randomized complete block design with three replicates in controlled growth chamber. Cotton seedlings in 2-3 true leaf stage were inoculated with $10^{7}$ conidia $\mathrm{ml}^{-1}$ spore suspension of $V$. dahliae which is leaf defoliating $\mathrm{T}_{1}$ pathotype by root dip technique. The differences between disease indexes from leaf and vascular tissues were significant $(\mathrm{P} \leq 0.01)$. Genotypes used in this study were categorized into 13 groups for leaf symptoms and 16 groups for vascular symptoms. Tamcot Camd-ES (1.39) from USA, PG 510-7 (1.64) and BA-525 (1.72) from Turkey were most resistant based on leaf symptoms. However, Tamcot Camd-ES (1.31) from USA, PG 5107 (1.47) and İH-26-K-5 from Turkey were the most resistant genotypes based on vascular symptoms. In this study a high positive correlation $(r=0.972)$ was found between diseases indexes from leaf and vascular tissues.

\section{Research Article}

$\begin{array}{ll}\text { Article History } & \\ \text { Received } & : 25.03 .2019 \\ \text { Accepted } & : 22.08 .2019\end{array}$

Keywords
Gossypium hirsutum
Verticillium dahlia
Leaf symptoms
Vascular tissue symptoms

To Cite: Akışcan Y, Tok FM 2019. Farklı Kökenli Bazı Pamuk Genotiplerinde Verticillium Solgunluğuna Dayanıklılı̆̆ın Araştırılması. KSÜ Tarım ve Doğa Derg 22(Ek Sayı 2): 354-360. DOI: 10.18016/ ksutarimdoga.vi.544323 


\section{GİRIŞ}

Ülkemizde başlıca öneme sahip tarımsal ürünlerden birisi olan pamuk, başta tekstil olmak üzere birçok sanayi kolunda hammadde olarak kullanılan stratejik bir üründür. Dünya nüfusunun hızla artmasına paralel olarak insanların yaşam biçimleri ve standartlarının da değişiklik göstermesi, pek çok üretim alanında olduğu gibi tekstil sanayisinin de önemini her geçen gün artırmaktadır. Ülkemizde 2015-2016 pamuk üretim sezonunda 738 bin ton pamuk üretim gerçekleşirken tüketim miktarı 1.656 milyon ton olmuştur (Özüdoğru 2017). Mevcut durum, Dünya'da önemli bir yere sahip olan tekstil sektörümüzün hammadde ihtiyacını önemli ölçüde karşılayamadığını ve hammadde ihtiyacı yönünden \% 55.4 oranda dışa bağımlı olduğunu göstermektedir. Hammadde ihtiyacımızın yerli üretimle karşılanabilmesi yönünden pamuk verim ve üretimimizin arttırılması büyük önem taşımaktadır. $\mathrm{Bu}$ bağlamda üretimin arttırılmasına yönelik olarak hastalık ve zararlı gibi verimi olumsuz yönde etkileyen faktörlerin minimize edilmesine yönelik çalışmaların yapılması büyük önem taşımaktadır.

Pamukta verimi etkileyen en önemli biyotik faktörlerden biri hastalıklardır. Verticillium solgunluğu hastalığının etmeni ve toprak kökenli bir fungus olan Verticillium dahliae Kleb. 400'ün üzerinde konukçuya sahiptir. Konukçuları arasında pamuğun yanı sıra enginar, biber, patlıcan, antepfistığı, zeytin, patates, çilek, domates, karpuz ve pek çok crusifer bitki yer almaktadır (Koike ve ark., 1994; Krikun ve Bemier, 1987; Subbarao ve ark., 1997). Fungusun toprakta mikrosklerot halinde 15 yıla kadar canlı kaldığı bilinmektedir (Agrios, 2005). Konukçuya ait kök salgılarıyla dormant dönemi sonlanan mikrosklerotlar çimlenerek çok erken dönemde bitki köklerinden giriş yapmaktadır. Daha sonra fungusun miselyumları kökte ilerleyerek iletim dokularına ulaşmakta ve ileriki aşamada sistemik enfeksiyona neden olmaktadır. İletim dokularında hızla çoğalan fungus burada su ve besin maddesi iletimini aksatmakta ve nihayetinde sona erdirmektedir (Gubler, 1996). Enfeksiyon çok erken dönemde başlasa da ilk belirtiler genellikle bitki tarak ve erken koza dönemindeyken görülmeye başlamaktadır. Erken dönemde çok şiddetli enfeksiyon olması durumunda bitkiler cüce kalabilmektedir. Enfekteli bitkilerin yapraklarında sararmalar ortaya çıkmakta, gövdesi enine kesildiğinde iletim dokularında kahverengileşmenin başladığı görülmektedir. Hastalığın ilerleyen dönemlerinde ise yaprak damar aralarından başlayan bir kuruma ortaya çıkmakta, iletim dokularındaki rengin de kahverengiden siyaha doğru dönüştüğü görülmektedir. Bu durum Verticillium solgunluğuna has çok karakteristik bir belirtidir (Karcılıŏlu ve ark., 1992). Bu tarz enfekteli bitkiler genellikle çok az sayıda koza taşımakta ve bu kozalar ya hiç açmamakta yada açsalar bile bunlardan elde edilecek pamukta lif kalitesinden söz etmek pek mümkün olmamaktadır (Korolev ve ark., 2001; P'erezArt'es ve ark., 2000). Verticillium dahiae'nin bazı patotiplerinde ve vejetatif uyum gruplarinda bitkilerde şiddetli yaprak dökümü ortaya çıkabilmektedir (Dobinson ve ark., 2000; Jim'enezD’1az ve ark., 2006; Göre 2007; Derviş ve ark, 2008). Pamukta Verticillium solgunluğu hastalığının mücadelesine yönelik yoğun çalışmalar yapılmaktadır. $\mathrm{Bu}$ hastalığın kontrolü amaciyla ekim nöbeti, dengeli gübreleme, dengeli sulama, yabancı ot mücadelesi gibi bazı kültürel işlemler önerilmektedir (Erdoğan ve ark., 2014). Ancak, geniş pamuk ekim alanlarında Verticillium solgunluğuna karşı etkin herhangi bir kimyasal ya da farklı bir savaşım yöntemi bulunmamaktadır. Bundan dolayı, hastalığın kontrolünde en etkili yöntemlerden birisi olarak dayanıklı çeşit kullanımı önerilmektedir (Wilhelm ve ark., 1974a,b; Schnathorst ve Cooper, 1975, Akışcan, 2011).

$\mathrm{Bu}$ çalışmanın amacı, bazı pamuk genotiplerin Verticillium solgunluğu hastalığına karşı dayanıklılık durumlarının tespit edilmesi ile ileride Verticillium solgunluğu hastalığına dayanıklılık konusunda yapılacak ıslah çalışmalarına dayanıklı anaç seçimi yönünden katkı sağlamaktır.

\section{MATERYAL ve METOT}

Bu çalışma, Hatay Mustafa Kemal Üniversitesi, Ziraat Fakültesi, Tarla Bitkileri ve Bitki Koruma Bölümü laboratuvarlarında 2015 yıllında yürütülmüştür. Çalışmada Çizelge 1'de verilen 42 pamuk (Gossypium hirsutum L.) genotipi bitki materyali, Derviş ve ark. (2008) tarafından yüksek virulentliğe sahip olduğu bildirilen $V$. dahliae patojeninin VCG1A grubunda yer alan 47 kodlu $\mathrm{T}_{1}$ (yaprak döken) patotipine ilişkin izolat ise hastalık materyali olarak kullanılmıştır. Çalışmaya ilişkin saksıda patojenite denemeleri, Gülümser ve ark. (2002) tarafindan kontrollü (homojen) koşullar için önerilen, tesadüf blokları deneme deseni uyarınca, 3 tekerrürlü (birbirini takip eden dönemler şeklinde) olarak yürütülmüştür. Bu kapsamda, yüzey sterilizasyonu yapllan pamuk tohumlarının ekimi yapılmış ve bitkiler $26 / 18{ }^{\circ} \mathrm{C}$ gündüz/gece sıcaklığında, 14 saat fotoperiyodla iklim kabininde yetiştirilmiştir. Genotiplerin Verticillium solgunluğu hastalığına dayanıklılıklarını belirlemek amaciyla, öncelikle izolatin PDA (Potato Dextrose Agar) ortamında tek sporları hazırlanmıştır. Tek sporlardan elde edilen 7 günlük taze kültürlerden alınan diskler tetrasiklin içeren (50 mg $\left.\mathrm{l}^{-1}\right)$ PDA ortamına aktarılmış ve $25{ }^{\circ} C^{\prime}$ ye ayarlanmış inkübatörde 1 hafta gelişmeye bırakılmıştır. Bu inkübasyonun sonunda patojenite testleri için spor solüsyonu hazırlamak amacıyla PDA besi ortamında geliştirilmiş kültürlerin üzerine steril saf su eklenerek 
konidilerin saf suya geçmesi sağlanmış, elde edilen süspansiyon, 4 kat tülbentten geçirilerek miselyal artıklar ile besi ortamları süspansiyondan uzaklaştırılmış ve bu süspansiyona Tween $20\left(100 \mu l l^{-}\right.$
1) eklenerek spor yoğunluğu Thoma Lamı ile mikroskop altında $10^{7}$ konidi $\mathrm{ml}^{-1}$ konsantrasyona ayarlanmıştır.

Çizelge 1. Materyal olarak kullanılan pamuk genotipleri ve kökenleri

\begin{tabular}{llll}
\hline Genotip & Köken & Genotip & Köken \\
\hline Acala-1517V & ABD & İH-26-K-5 & Türkiye \\
DP-499 & ABD & İH-27-TYL & Türkiye \\
Prema & ABD & İH-82-K-3 & Türkiye \\
ST-468 & ABD & İH-82-Y-1 & Türkiye \\
Tamcot Camd-ES & ABD & Lydia & Türkiye \\
Tamcot SP37H & ABD & PG 424-1 & Türkiye \\
Tamcot Sphinx & ABD & PG 426-4 & Türkiye \\
Gloria & Avusturalya & PG 510-15 & Türkiye \\
Natalia & Bulgaristan & PG 510-7 & Türkiye \\
MCH-578 & Hindistan & PG 511-7 & Türkiye \\
H-4028 & İsrail & PG 518-11 & Türkiye \\
Taskent-1 & Özbekistan & PG 519-19 & Türkiye \\
Taşkent-3 & Özbekistan & PG 520-7 & Türkiye \\
CIM-496 & Pakistan & PG 53-KT-2 & Türkiye \\
BA-151 & Türkiye & PG 53-YT-11 & Türkiye \\
BA-320 & Türkiye & PG-2018 & Türkiye \\
BA-525 & Türkiye & PG-300 & Türkiye \\
BA-811 & Türkiye & PG-310 & Türkiye \\
Carisma & Türkiye & VD-4 & Türkiye \\
Cukurova 1518 & Türkiye & BA-308 & Yunanistan \\
IH-20 & Türkiye & Teks & Yunanistan \\
\hline
\end{tabular}

İnokulasyon işlemi, 2-3 gerçek yaprağa sahip pamuk bitkilerinin kökleri su ile yıkandıktan sonra yüzeyden sterilize edilmiş makasla tıraşlanarak hazırlanan spor süspansiyona daldırılmasıyla yapılmıştır. $\mathrm{Bu}$ kapsamda, her bir pamuk genotipinden 12 adet bitki patojenle muamele edilirken, 4 adet bitki de kontrol amacıyla aynı şekilde steril saf su ile muamele edilmiştir. Daldırma işlemi sonrasında bitkiler steril edilmiş torf, perlit ve bahçe toprağ (1:1:1) içeren 10x10 $\mathrm{cm}$ boyutlarındaki saksılara her bir saksıya aynı genotipten 4 bitki olacak şekilde aktarılmıştır. Bu işlem sonrası bitkiler iklim kabinine yerleştirilmiş ve anılan koşullarda gelişmeye bırakılmıştır. Saksıların toprak nemi günlük olarak gravimetrik yöntemle kontrol edilmiş ve eksilen su tarla kapasitesinin \% 65'ine tamamlanmıştır. Daldırma işleminden 37 gün sonra yaprak ve iletim dokusu semptomları dikkate alınarak hastalığa ilişkin değerlendirme işlemi yapılmıştır. Yaprak semptomlarına göre hastalık şiddeti değerleri, Verticillium solgunluğu hastalığının pamuk bitkilerinin yapraklarında meydana getirdiği semptomlar esas alınarak, 0 - 4 yeşil aksam skalasına göre (0: gözle görülür bir semptom yok; 1: yapraklarda yeni başlamış solgunluk ya da önemsiz sararmalar gibi az ve kesin olmayan semptomlar; 2 ve 3 : yapraklarda sararma, damarlar arası nekroz, yaprak dökülmesi ve uçtan itibaren geriye doğru ölüm;4: ölmüş veya ölmekte olan bitki) bitkiler tek tek incelenerek hastalık şiddetleri (Şekil 1) saptanmıştır (Wilhelm ve ark. 1974a,b). İletim dokusu semptomlarına göre hastalık şiddeti değerleri ise Verticillium solgunluğu hastalığının pamuk bitkilerinin gövde kesitlerinde meydana getirdiği semptomlar esas alınarak, $0-4$ gövde semptomu skalasına göre (0: iletim dokularında renk bozulması yok; 1: odun dokusunda \% 1-25 renk bozulmasi; 2: odun dokusunda \%26-50 renk bozulmasi; 3: odun dokusunda \% 51-75 renk bozulmasi; 4: odun dokusunda \%76-100 renk bozulmasl) bitkiler tek tek incelenerek hastalık şiddetleri belirlenmiştir (Bhat ve Subbarao, 1999). Ardından saptanan hastalık şiddeti değerleri kullanılarak eşitlik 1 aracılığı ile yaprak ve iletim dokusu semptomlarına göre hastalık indeksi değerleri hesaplanmıştır. Anılan eşitlikte " $0,1,2,3$, 4" hastalık şiddetine ilişkin skala değerlerini, " $\mathrm{a}, \mathrm{b}, \mathrm{c}, \mathrm{d}$, e" her bir skala değerine giren bitki sayısını, "n" ise toplam bitki sayısını göstermektedir (Karman, 1971). Hesaplanan hastalık indeksi değerleri 2'den 0'a doğru gittikçe hastalığa dayanıklılığın artığını ifade ederken, 2'den 4'e doğru gittikçe hastalığa hassasiyetin arttığını ifade etmektedir.

$$
\text { Hastalık İndeksi }=\frac{0 \mathrm{a}+1 \mathrm{~b}+2 \mathrm{c}+3 \mathrm{~d}+4 \mathrm{e}}{\mathrm{n}}
$$

Genotiplere ilişkin olarak elde edilen yaprak ve iletim dokusu semptomlarına göre, hastallk indeksi değerleri, SAS istatistik paket programı (SAS Institute Inc., 1998) aracılığı ile tesadüf blokları deneme deseni uyarinca varyans analizine tabi tutulmuş ve ortalamalar arasındaki farklılıklar $\mathrm{F}$ testi 
uyarınca irdelenerek DUNCAN testi vasitası ile $\mathrm{P}<0.05$ önem seviyesinde gruplandırılmıştır. Korelasyon analizi ise JMP v.10 (SAS Institute Inc., 2012) istatistik paket programı aracılığı ile yapılmıştır.

\section{BULGULAR}

Farklı kökenli pamuk genotiplerine ilişkin olarak yapilan varyans analizi sonucunda, yaprak ve iletim dokusu semptomlarına göre hastalık indeksi değerleri yönünden genotipler arasında, istatistiksel olarak $\mathrm{P}<0.01$ düzeyinde, önemli farklılık olduğu saptanmıştır (Çizelge 2).

Calışma sonucunda elde edilen yaprak semptomlarına göre hastalık indeksi değerleri incelendiğinde istatistiksel olarak 13 farklı grup oluşmuştur (Çizelge 3). En düşük hastalık indeksi değerine sahip genotiplerin yer aldiğ 1 "m" grubunda bulunan ABD kökenli Tamcot Camd-ES (1.39) hastallk indeksi değeri en düşük genotip olurken Türkiye kökenli PG 510-7 (1.64) ve BA-525 (1.72) onu takip etmiştir.

Çizelge 2. Hastalık indeksi değerlerine ait varyans analiz sonuçları

\begin{tabular}{lccc} 
Varyasyon & Serbestlik & \multicolumn{2}{c}{ Kareler Ortalaması } \\
Kaynağı & Derecesi & $\begin{array}{c}\text { Yaprak semptomlarına göre, } \\
\text { hastalık indeksi }\end{array}$ & $\begin{array}{c}\text { Illetim dokusu semptomlarına göre, } \\
\text { hastallk indeksi }\end{array}$ \\
\hline Bloklar & 2 & 0.361 & 0.411 \\
Genotipler & 41 & $23.180^{* *}$ & $0.552^{* *}$ \\
Hata & 82 & 4.825 & 0.067 \\
\hline C.V. (\%) & & 9.93 & 10.74 \\
\hline
\end{tabular}

** istatistiksel olarak $\mathrm{P}<0.01$ düzeyinde önemlidir.

Çizelge 3 incelendiğinde, yaprak semptomları yönünden dayanıklı genotiplerin yer aldığı 0 ile 2 indeks değerleri arasında 9 pamuk genotipi olduğu, bunlardan 4'ünün (Tamcot Camd-ES, ST-468, Tamcot SP37H, DP-499) ABD kökenli, 5'inin ise (PG 510-7, BA-525, İH-26-K-5, PG 53-KT-2, Lydia) Türkiye kökenli olduğu dikkat çekmektedir. Verticillium solgunluğuna hassas genotiplerin bulunduğu 2 ile 4 indeks değeri arasında 33 pamuk genotipi bulunmaktadır. Yaprak semptomlarına göre Verticillium solgunluğuna en hassas genotiplerin yer aldığı "a" grubunda (3.14-2.67) ise aralarında ABD, İsrail, Özbekistan, Pakistan ve Türkiye kökenli 5 farklı ülkeden 17 genotip (VD-4, İH-27-TYL, PG 51919, Taşkent-1, H-4028, Çukurova 1518, PG 518-11, PG 520-7, PG-310, CIM-496, PG 426-4, PG 510-15, Acala1517V, PG-2018, Carisma, Prema ve BA-811) yer almıştır. Bunlardan VD-4 genotipinin istatistiksel olarak aynı grupta yer almakla birlikte yaprak semptomlarina göre 3.14 indeks değeri ile en hassas genotip olduğu tespit edilmiştir (Çizelge 3).

İletim dokularına göre hastalık indeksi değerleri istatistiksel olarak 16 farklı grup oluşturmuştur. En düşük hastalık indeksi değerine sahip genotiplerin bulunduğu "p" grubunda 3 genotip yer almaktadır (Çizelge 3). Bunlardan ABD kökenli Tamcot Camd-ES (1.31) hastalık indeksi değeri en düşük genotip olurken Türkiye kökenli PG 510-7 (1.47) ve İH-26-K-5 ise onu takip etmiştir. İletim dokusu semptomları yönünden dayanıklı genotiplerin bulunduğu 0 ile 2 indeks değeri arasında yer alan 8 genotip olduğu, bunlardan 3’ünün ABD (Tamcot Camd-ES, ST-468, Tamcot SP37H), 1'inin Avustralya (Gloria) ve geri kalan 4'ünün ( PG 510-7, $\mathrm{I} H-26-\mathrm{K}-5$, BA-525, Lydia) ise Türkiye kökenli olduğu dikkat çekmektedir. İletim dokusu yönünden hassas genotiplerin yer aldığı 2 ile 4 indeks değeri arasında aralarında ABD, Avustralya, Hindistan,
İsrail, Özbekistan, Pakistan, Türkiye ve Yunanistan'ın olduğu 8 farklı ülke kökenli 34 genotipin yer aldığı 14 farklı istatistiksel grup oluşmuştur. İletim dokusu semptomlarina göre Verticillium solgunluğuna en hassas genotiplerin bulunduğu "a" grubunda (3.112.64) ise 6 farklı ülkeden 18 farklı genotip (VD-4, H4028, Taşkent-1, İH-27-TYL, PG 519-19, Çukurova 1518, PG 518-11, PG-310, PG 53-YT-11, Acala-1517V, PG 520-7, MCH-578, CIM-496, PG 510-15, PG 511-7, PG-2018, Carisma, PG 426-4) yer almiştır. Bu gruptaki VD-4 genotipi, iletim dokusu semptomlarına göre 3.11 indeks değeri ile en hassas genotip olarak belirlenmiştir.

\section{TARTIŞMA VE SONUÇ}

Kontrollü koşullarda iklim kabininde yürütülen bu çalışma sonucunda, genotiplere ilişkin olarak yaprak ve iletim dokularındaki semptomlara göre elde edilen hastalık indeksi değerleri arasında yüksek düzeyde pozitif yönde korelasyon $(r=0.972)$ olduğu saptanmıştır (Şekil 1). Konuyla ilgili olarak Lüders ve ark. (2008), sera koşullarında yaptıkları çalışmada, inceledikleri Backcross 2 popülasyonunda hastalık indeksi değerlerini yaprakta 1.82 , iletim dokularında $3.34, \mathrm{~F}_{1}$ popülasyonunda ise yaprakta 2.14 , iletim dokularında 2.52 olarak saptamıştır. Buradan yaprak ve iletim dokusu semptomlarına göre hastalık indeksi değerlerinin Backcross 2 popülasyonunda 1.51 sapma gösterdiği ancak $\mathrm{F}_{1}$ popülasyonunda sapmanın sadece 0.38 olduğu görülmektedir. Karademir ve ark. (2010) ise tarla koşullarında inceledikleri tüm pamuk genotiplerinde $V$. dahliae'nin meydana getirdiği yaprak ve iletim dokusu semptomlarına göre hastalık indeksi değerlerinin birbirine yakın seyrettiğini bildirmişlerdir.

Benzer şekilde Khaskheli ve ark. (2013) sera ve tarla koşullarında yaptıkları çalışmada, inceledikleri tüm 
genotiplerde yaprak ve iletim dokusuna göre hastalık indeksi değerleri arasında çok yüksek derecede pozitif korelasyon ( $\mathrm{r}=0.966$ ) olduğunu bildirirken Zhou ve ark. (2014) 2013 yılında tarla koşullarında yaptıkları 3 farklı denemede yaprak ve iletim dokusu semptomlarına göre hastalık indeksi değerleri arasında birinci denemede önemsiz ve yok denecek kadar düşük $(r=0.03)$, ikinci denemede önemli ve düşük $(r=0.39)$ ve üçüncü denemede ise orta derecede önemli pozitif korelasyon değerleri $(r=0.58)$ saptamışlardır. Farklı çalışmalarda araştırıcıların aynı bitkiler üzerinden hastalığa ilişkin olarak aldıkları yaprak ve iletim dokusu semptomlarına ait değerler arasında zaman zaman önemli derecede farklılıklar olduğu dikkat çekmektedir. Bu durumun, tarla ve sera gibi çevre koşullarının kontrolsüz veya net olarak kontrol edilemediği koşullarda, bitki yapraklarının hastalık, zararlı, ilaçlama, besin maddesi noksanlığ 1 veya fazlalığı gibi birçok biyotik ve abiyotik faktörün etkisine açık olmasından kaynaklandığı düşünülmektedir. Bu nedenle, özellikle

Çizelge 3. Farklı kökenli pamuk genotiplerinde saptanan hastalık indeksi değerleri ve oluşan gruplar

\begin{tabular}{|c|c|c|}
\hline Genotipler & $\begin{array}{c}\text { Yaprak Semptomlarına Göre, } \\
\text { Hastalık İndeksi* }\end{array}$ & $\begin{array}{c}\text { İletim Dokusu Semptomlarına Göre, } \\
\text { Hastalık İndeksi }\end{array}$ \\
\hline Acala-1517V & 2.69 abcde & 2.72 abcdefg \\
\hline BA-151 & 2.42 defgh & 2.28 fghijklm \\
\hline BA-308 & 2.36 defghi & 2.33 efghijklm \\
\hline $\mathrm{BA}-320$ & 2.58 bcdefg & 2.58 bcdefghij \\
\hline $\mathrm{BA}-525$ & $1.72 \mathrm{klm}$ & $1.84 \mathrm{mno}$ \\
\hline BA- 811 & 2.67 abcdef & 2.50 cdefghijk \\
\hline Carisma & 2.67 abcdef & 2.64 abcdefghi \\
\hline CIM-496 & 2.75 abcd & 2.67 abcdefgh \\
\hline Çukurova $1518^{*}$ & $2.92 \mathrm{abc}$ & 2.86 abcd \\
\hline DP-499 & 1.97 hijkl & 2.22 ghijklmn \\
\hline Gloria & 2.11 ghijk & $2.00 \mathrm{klmn}$ \\
\hline $\mathrm{H}-4028$ & $2.92 \mathrm{abc}$ & $3.03 \mathrm{ab}$ \\
\hline İH-20 & 2.42 defgh & 2.39 defghijkl \\
\hline İH-26-K-5 & $1.83 \mathrm{jkl}$ & 1.72 nop \\
\hline İH-27-TYL & $3.06 \mathrm{ab}$ & $2.94 \mathrm{abc}$ \\
\hline İH-82-K-3 & 2.36 defghi & 2.28 fghijklm \\
\hline İH-82-Y-1 & 2.42 defgh & 2.28 fghijklm \\
\hline Lydia & 2.00 hijkl & 1.92 lmno \\
\hline MCH-578 & 2.58 bcdefg & 2.67 abcdefgh \\
\hline Natalia & 2.20 fghij & 2.19 hijklmn \\
\hline PG 424-1 & 2.64 bcdef & 2.47 cdefghijk \\
\hline PG 426-4 & 2.75 abcd & 2.64 abcdefghi \\
\hline PG 510-15 & 2.72 abcd & 2.67 abcdefgh \\
\hline PG 510-7 & $1.64 \mathrm{~lm}$ & 1.47 op \\
\hline PG 511-7 & 2.58 bcdefg & 2.61 abcdefghi \\
\hline PG 518-11 & $2.92 \mathrm{abc}$ & 2.80 abcde \\
\hline PG 519-19 & $3.06 \mathrm{ab}$ & $2.97 \mathrm{abc}$ \\
\hline PG 520-7 & $2.92 a b c$ & 2.72 abcdefg \\
\hline PG 53-KT-2 & $1.89 \mathrm{jkl}$ & $2.03 \mathrm{klmn}$ \\
\hline PG 53-YT-11 & 2.61 bcdef & 2.78 abcdef \\
\hline PG-2018 & 2.67 abcdef & 2.61 abcdefghi \\
\hline PG-300 & 2.50 cdefg & 2.56 bcdefghij \\
\hline PG-310 & 2.81 abcd & 2.81 abcde \\
\hline Prema & 2.67 abcdef & 2.55 bcdefghij \\
\hline $\mathrm{ST}-468$ & $1.84 \mathrm{jkl}$ & $1.89 \mathrm{lmno}$ \\
\hline Tamcot Camd-ES & $1.39 \mathrm{~m}$ & $1.31 \mathrm{p}$ \\
\hline Tamcot SP37H & $1.92 \mathrm{ijkl}$ & 1.92 lmno \\
\hline Tamcot Sphinx & 2.03 hijkl & 2.08 jklmn \\
\hline Taşkent-1 & 2.94 abc & $3.03 \mathrm{ab}$ \\
\hline Taşkent-3 & 2.22 efghij & $2.14 \mathrm{ijklmn}$ \\
\hline Teks & 2.11 ghijk & $2.14 \mathrm{ijklmn}$ \\
\hline $\mathrm{VD}-4^{*}$ & $3.14^{\mathrm{a}}$ & $3.11 \mathrm{a}$ \\
\hline
\end{tabular}

*Farklı harflerle gösterilen değerler DUNCAN testine göre \% 5 önem seviyesinde farklıdır. 
tarla koşullarında yapılacak çalışmalarda gerek iş yükünün azaltılması, gerekse yaprakların yukarıda belirtildiği gibi pek çok faktörün etkisine açık ve kolayca etkilenebilir olması sebebiyle tarla ve sera gibi koşullarda yapılacak Verticillium'a dayanıklılığın belirlenmesine yönelik yapılacak çalışmalarda daha sağlıklı sonuçlar elde edilebilmesi yönünden iletim dokusu semptomlarina göre hastalık indeksi değerlerinin kullanılması önerilebilir.

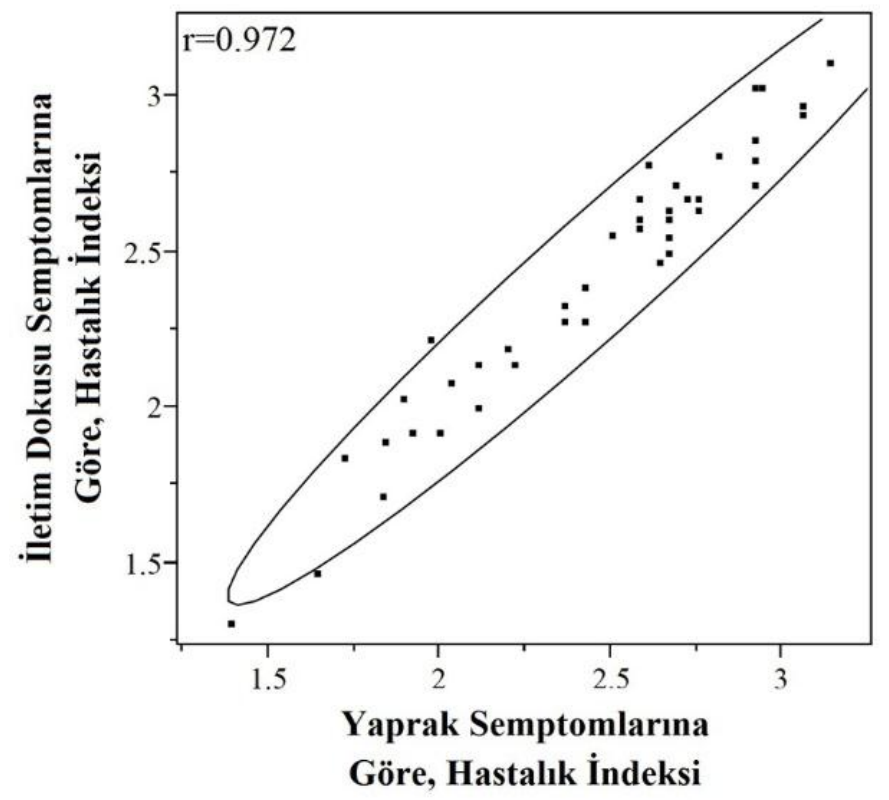

Şekil 1. Genotiplerin hastalık indeksi değerlerine ilişkin korelasyon tablosu

\section{TEŞEKKÜR}

Bu çalışma, TÜBİTAK (Türkiye Bilimsel ve Teknolojik Araştırma Kurumu) tarafından 214 O 086 kodu ile öncelikli alanlar Ar-Ge projelerini destekleme programı kapsamında desteklenmiştir. TÜBİTAK'a finansal desteği için teşekkürlerimizi sunarız. Bu çalışmaya ilişkin bulguların bir kısmı 2017 yılında Romanya'da düzenlenen kongrede (International Conference "Agriculture for Life, Life for Agriculture") özet olarak yayınlanmıştır.

\section{KAYNAKLAR}

Agrios GN 2005. Plant Pathology (5th edition). Department of Plant Pathology, University of Florida, Elsevier Academic Pres. USA, page: 527.

Akışcan Y 2011. Pamukta (Gossypium hirsutum L.) Verticillium Solgunluğu (Verticillium dahliae Kleb.) Hastalığına Dayanıklılık, Erkencilik, Verim ve Kalite Özelliklerinin Kalıtımı. Çukurova Üniversitesi, Fen Bilimleri Enstitüsü, Tarla Bitkileri ABD, Doktora Tezi.

Bhat RG, Subbarao KV 1999. "Host range specificity in Verticillium dahliae", Phytopathology, 89:12181225.

Derviş S, Kurt Ş, Soylu S, Erten L, Soylu EM, Yıldız
M, Tok FM 2008. "Vegetative compatibility groups of Verticillium dahliae from cotton in the southeastern anatolia region of Turkey. Phytoparasitica, 36(1):74-83.

Dobinson KF, Harrington MA, Omer M and Rowe RC (2000) Molecular characterization of vegetative compatibility group $4 \mathrm{~A}$ and $4 \mathrm{~B}$ isolates of Verticillium dahliae associated with potato early dying. Plant Dis., 84:1241-1245.

Erdoğan O, Kurt Ş, Göre E 2014. Pamukta Verticillium Solgunluk Hastalığı Etmeni Verticillium dahliae Kleb. ile Farklı İnokulasyon Metotları Üzerinde Çalışmalar. Türk Tarım ve Doğa Bilimleri Dergisi, 1(2):188-193.

Göre ME 2007. Vegetative Compatibility and Pathogenicity of Verticillium dahliae Isolates from the Aegean Region of Turkey. Phytoparasitica, 35(3): 222-231.

Gubler WD 1996. Verticillium wilt. in: Zitter TA, Hopkins LD, Thomas CE [Eds.] Compendium of Cucurbit Diseases. APS Press, St. Paul, MN, USA.

Gülümser A, Bozoğlu H, Pekşen E 2002. Araştırma ve Deneme Metodları, Ondokuz Mayıs Üniversitesi, Ziraat Fakültesi. Ders kitabı No: 48.

Jim'enez-D'ıaz RM, Mercado-Blanco J, OlivaresGarc'ıa C, Collado-Romero M, Bejarano-Alc'azar J, Rodr'iguez-Jurado D, Giménez-Jaime A, GarcíaJiménez J, Armengol J 2006. Genetic and virulence diversity in Verticillium dahliae populations infecting artichoke in eastern-central Spain. Phytopathology, 96:288-298.

Karademir E, Karademir Ç, Ekinci R, Baran B, Sağır A 2010. Assessment of Tolerance Level of some Cotton (Gossypium hirsutum L.) Varieties against Verticillium wilt (Verticillium dahliae Kleb.). Not. Bot. Hort. Agrobot. Cluj, 38(1):196-202.

Karcılıŏlu A, Onan E, Sezgin E 1992. Bazı pamuk çeşitlerinin Verticillium dahliae Kleb. Fungusunun neden olduğu solgunluk hastalığına karşı duyarlılıklarının saptanması üzerinde araştırmalar. İzmir. Zirai Mücadele Araştırma Yıllığı No: 22-23, s. 138.

Karman M 1971. Bitki Koruma Araştırmalarında Genel Bilgiler. Tarım Bakanlığı, Mesleki Kitaplar Serisi, s. 279, Bornova-İzmir.

Khaskheli MI, Sun JL, He SP, Du XM 2013. Screening of cotton germplasm for resistance to Verticillium dahlia Kleb. under greenhouse and field conditions. Eur J Plant Pathol., 137:259-272.

Koike ST, Subbarao KV, Davis RM, Gordon TR, Hubbard JC 1994. Verticillium wilt of cauliflower in California. Plant Dis., 78: 1116- 1121.

Korolev N, P'erez-Art'es E, Bejarano-Alc'azar J, Rodr'iguez-Jurado D, Katan J, Katan T, JimenezDiaz RM 2001. Comparative study of genetic diversity and pathogenicity among populations of Verticillium dahliae cotton in Spain and Israel. Eur. 
J. Plant Pathol., 107:443-456.

Krikun J, Bernier CC 1987. Infection of several crop species by two isolates of Verticillium dahliae. Can. J. Plant Pathol., 9: 241-245

Lüders RR, Galbieri R, Fuzatto MG, Cia E 2008. Inheritance of resistance to Verticillium wilt in cotton. Crop Breeding and Applied Biotechnology, 8: 265-270, 2008.

McCain AH, Raabe RD, Wilhelm S 1981. Plants resistant or susceptible to Verticillium wilt. Cooperative extension, US Department of Agriculture, University of California.

Özüdoğru T 2017. Durum ve Tahmin Pamuk 2017/2018. Tarımsal Ekonomi ve Politika Geliştirme Enstitüsü. Yayın No: 285. Yenimahalle, Ankara.

P'erez-Art'es E, Garc'ia-Pedrajas MD, BejaranoAlc'azar J, Jim'enez-D'iaz RM 2000. Differentiation of cotton-defoliating and nondefoliating pathotypes of Verticillium dahliae by RAPD and specific PCR analyses. Eur. J. Plant Pathol., 106:507-517.

SAS Institute Inc. 1998. SAS/STAT User's Guide, Version 6. SAS Institute Inc., Cary, NC, USA.

SAS Institute Inc. 2012. JMP v.10 Discovering JMP. Cary, NC, USA: SAS Institute Inc.
Schnathorst WC, Cooper JR 1975. Anomalies in Field and Greenhouse Reaction of Certain Cotton Cultivars in Fected with Verticillium dahliae. In Proc. Beltwide Cotton Prod. Conf., 6-8 January, New Orleans, National Cotton Council, Memphis, p. $148-149$.

Subbarao KV, Hubbard JC, Greathead AS, Spencer GA 1997. Verticillium wilt. In: Compendium of Lettuce Diseases (Eds.: R.M. Davis, K.V. Subbarao, R..N. Raid and E.A. Kurtz). The American Phytopathological Society, St. Paul, MN, USA, pp. 26-27.

Wilhelm S, Sagen JE, Tietz H 1974a. "Resistance to Verticillium wilt in cotton: sources, techniques of identification, inheritance trends, and the resistance potential of multiline cultivars", Phytopathology, 64: 924-931.

Wilhelm S, Sagen JE, Tietz H 1974b. "Gossypium hirsutum subsp. mexicanum var. nervosum, Leningrad Strain, A source of resistance to Verticillium Wilt", Phytopathology, 64:931-939.

Zhou H, Fang H, Sanogo S, Hughs SE, Jones DC, Zhang J 2014. Evaluation of Verticillium wilt resistance in commercial cultivars and advanced breeding lines of cotton. Euphytica, 196:437-448.. 